- $1 \%$ of the papers reported whether consent was sought or granted for the donations and only $7 \%$ of papers included a statement that no organs from prisoners were used.

The authors conclude that a large number of the studies conducted before 2015 probably contain data from executed prisoners, given that China says prisoners were a source of organs at this time.

Nature contacted six journals that each published ten or more of the 445 papers in the BMJ Open analysis.

Joerg Heber, editor-in-chief of PLoS ONE, which published 15 papers without information on the source of organs that were cited in the study, and one without an ethics statement, told Nature that the journal has been investigating articles for which the source of organs is unclear.

"I strongly believe that any research involving human participants or organ transplantations must follow the highest ethical standards," says Heber. The journal will retract papers if it becomes clear that ethical standards have not been met, he says.

The journal Liver Transplantation published 12 papers cited in the BMJ Open study that didn't include details of organ origin, and 3 without ethics statements. A spokesperson says that before the study was published, Liver Transplantation already had a policy of asking authors submitting papers to confirm that their data do not come from executed prisoners. They say the journal has not launched an investigation, but will retract a paper if it becomes clear after publication that it contains data from executed prisoners. The other four journals have yet to respond to Nature's questions.

And the journal Transplantation, which is also named in the BMJ Open study, has moved to retract papers that lack details of the origin of the organs. In an editorial posted online on 5 June, the journal said that it had investigated nine papers, including five cited in the BMJ Open study (J. R. Chapman et al. Transplantation http://doi.org/ c7nj; 2019). In one case, the author was able to provide a satisfactory description of the single transplant described in the paper, and another paper was published before the journal had clear guidelines on donor-reporting requirements. In the other seven cases, neither the authors nor their institutions had offered explanations. Editor-in-chief Jeremy Chapman told Nature that the journal will retract the seven papers in its August issue.

Springer Nature, which publishes several of the journals named in the analysis, is concerned by the findings and is investigating the papers reported, says Suzanne Farley, director of research integrity at Springer Nature in London. "We will not hesitate to take editorial action in cases where appropriate," she says. (Nature's news team is editorially independent of its publisher, Springer Nature.)

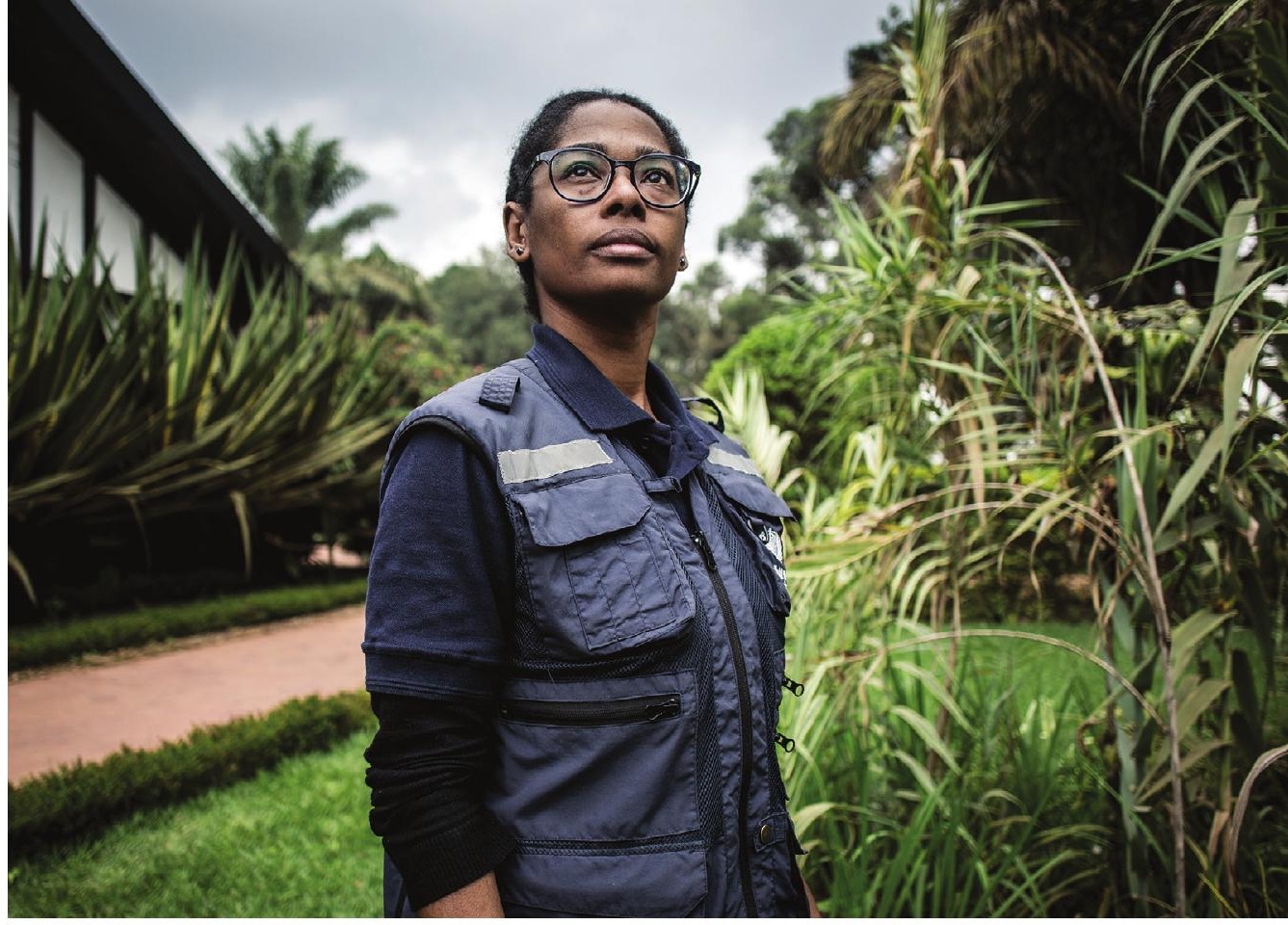

Haitian epidemiologist Marie-Roseline Darnycka Bélizaire is helping to coordinate the Ebola response.

SOCIETY

\title{
Battling Ebola
}

in a war zone

\section{Health workers in the Democratic Republic of the Congo face violence as they battle deadly virus.}

\section{BY AMY MAXMEN,}

\section{BENI, DEMOCRATIC REPUBLIC OF THE CONGO}

A crack runs down one window of the armoured vehicle transporting epidemiologist Mamoudou Harouna Djingarey through Beni, a city in the eastern Democratic Republic of the Congo (DRC). An outbreak of the Ebola virus has killed nearly 1,500 people in the region since August, but it is not the only danger that Djingarey and other Ebola responders must confront.

The window cracked on 5 June, when townspeople in Beni hurled rocks at a convoy of vehicles carrying staff from the World Health Organization (WHO), the DRC Ministry of Health and other authorities. One stone hit the head of a traditional leader from the neighbouring Butembo district, who was travelling in the convoy. He survived, but was hospitalized for several days.

Such clashes neither deter nor bewilder Djingarey, a programme manager at the WHO. "We just need to ask them why they

This story was supported by the Pulitzer Center on Crisis Reporting. throw stones," he says. The crowd that attacked the convoy was upset that officials and health workers drove through a checkpoint without stopping to wash their hands in chlorinated water, as local residents have been ordered to do.

"We must also respect the rules," Djingarey says. After all, he says, Ebola responders need to win the trust of those they are trying to help.

That is a difficult task in the eastern DRC, where more than a dozen armed groups have killed millions of civilians over the past 25 years

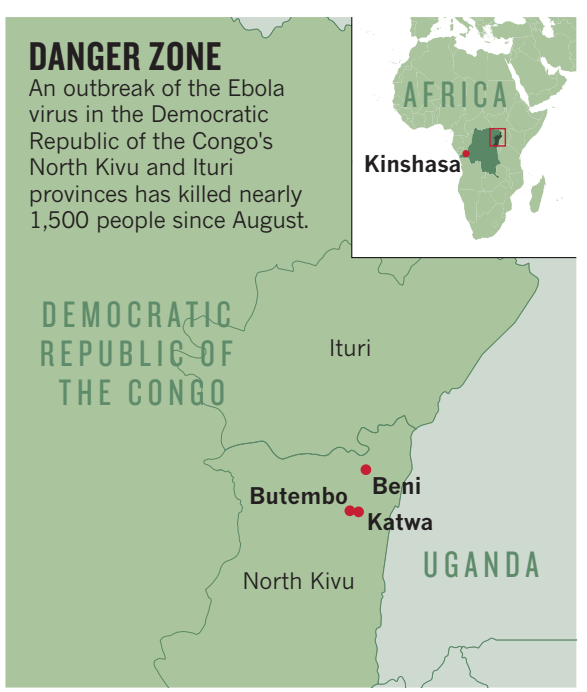


The region's residents have also endured decades of mineral exploitation, controversial interventions from the United Nations and foreign governments, and political corruption.

Now, Ebola responders are asking for the trust of communities that had never heard of this strange and terrifying disease before the current outbreak - and many residents are wary. Conflicts unrelated to Ebola are also surging. At least 160 people have been massacred in the eastern DRC during the past few weeks, and 300,000 people have fled violence in Ituri, one of the two provinces where Ebola is spreading (see 'Danger zone').

Vanishingly few humanitarian and health organizations will send health workers to battle Ebola under such conditions, but the WHO remains.

Marie-Roseline Darnycka Bélizaire, a Haitian epidemiologist, is helping to coordinate the WHO's Ebola response in Katwa, a town in the DRC's North Kivu province. "It is very intense, but I am totally devoted to serving the people," she says.

When Bélizaire's team chases the virus into a new town, she tries to meet with different groups in the community to explain what the health workers are doing, and why. "If you go to New York, you would talk with the gangsters, the vendors, all the different types of people," says Bélizaire. "So I talk with them and explain Ebola and why they need to take care."

She is all too aware of the dangers that such work can bring. In mid-April, Bélizaire visited another epidemiologist, Richard Mouzoko, at

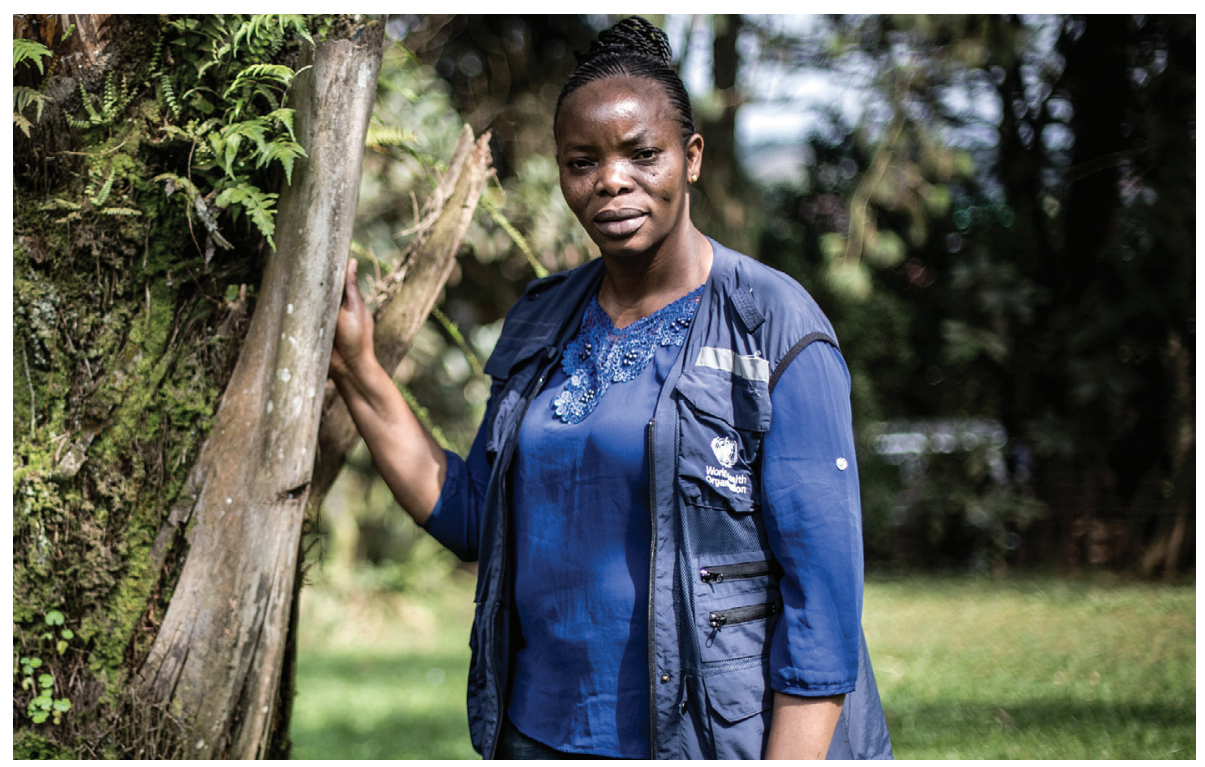

Marie-Claire Kolié, a doctor from Guinea, works at a treatment centre that has been shot at and set on fire.

a hospital in Butembo to discuss a patient. The next day, assailants stormed the ward and shot and killed Mouzoko.

Bélizaire eventually returned to the hospital, where walls are pocked with bullet marks from the attack that killed Mouzouko. "Even if you are down, you cannot be down, because when you are a leader, you need to be strong," she says. "If I am not strong, they will say this job is not for women."

On a warm June day, Bélizaire is sitting in the shade with Marie-Claire Kolié, a
Guinean doctor and veteran of the largest Ebola epidemic on record, which struck West Africa from 2014 to 2016. Kolié has had her own brush with violence during this outbreak. She was on her way to work at an Ebola treatment centre in February when assailants shot at the facility and set it on fire.

Kolié still treats people at the centre, which is now fortified by a barricade and snipers and she rejects the idea that doing so is brave. "It's nothing special," she says. "Everyone here knows it is dangerous, but we're committed." -

\section{Iranian biologists face US trial for trying to transport proteins}

\section{At issue is whether growth factors are exempt from export restrictions.}

\section{BY MICHELE CATANZARO \& SARA REARDON}

$\mathrm{T}$ Three Iranian biologists are facing trial in a US court over charges that they violated trade sanctions by attempting to export chemicals known as growth factors, which are commonly used in medical research.

The scientists have asked a federal district court judge in Atlanta, Georgia, to dismiss the criminal charges against them. They argue that the materials in question - eight vials of proteins that scientists use to help culture cells are exempt from US controls on exports to Iran because they are used for medical purposes. But the government says that the researchers violated the law by attempting to "smuggle" the chemicals to Iran without permission from the US treasury department's Office of Foreign Assets Control (OFAC).

On 17 June, government prosecutors filed their response to the scientists' motions to dismiss the case; the scientists have until 1 July to reply. The judge handling the case will then decide whether it goes to trial.

One of the defendants, Masoud Soleimani, a prominent stem-cell researcher at Tarbiat Modares University in Tehran, has spent eight months in an Atlanta jail. The others, former students of Soleimani's who live in the United States, are free on bail.

Legal experts say that the case highlights the confusion surrounding the United States' complex policies on Iran, which have undergone major changes twice since 2015. Many lawyers who specialize in US national-security issues are surprised that the government brought criminal charges against the Iranian researchers, rather than treating the matter as a regulatory issue and imposing a fine.

"I don't see any evidence that there was criminal intent here," says Clif Burns, a lawyer at Crowell \& Moring in Washington DC. He says that government prosecutors have not presented any evidence suggesting that the scientists attempted to hide the vials of growth hormone - for instance, by disguising them as another substance during transport.

Kevin Wolf, a lawyer at Akin Gump in Washington DC, says that violations of OFAC regulations are usually settled out of court and rarely proceed to trial by jury. In criminal 